\title{
STUDI PARAMETER DESAIN TERAS INTEGRAL PRESSURIZED WATER REACTOR DENGAN BAHAN BAKAR MIXED OXIDE FUEL MENGGUNAKAN PROGRAM SRAC
}

\author{
Harun Ardiansyah', Alexander Agung ${ }^{2}$, Andang Widi Harto ${ }^{3}$
}

1) Departemen Teknik Nuklir dan Teknik Fisika, Fakultas Teknik, Universitas Gadjah Mada, Sleman, Indonesia, (harun.ardiansyah@mail.ugm.ac.id)

2) Departemen Teknik Nuklir dan Teknik Fisika, Fakultas Teknik, Universitas Gadjah Mada, Sleman, Indonesia, (a_agung@ugm.ac.id)

3) Departemen Teknik Nuklir dan Teknik Fisika, Fakultas Teknik, Universitas Gadjah Mada, Sleman, Indonesia, (andangwh@ugm.ac.id)

\begin{abstract}
ABSTRAK
STUDI PARAMETER DESAIN TERAS PWR INTEGRAL DENGAN BAHAN BAKAR MOX MENGGUNAKAN PROGRAM SRAC. PWR Integral menggunakan bahan bakar MOX dapat menjadi solusi untuk mengatasi permasalahan elektrifikasi di negara kepulauan dan mengakomodasi pergantian bahan bakar dari $\mathrm{UO}_{2}$ menuju MOX. PWR Integral merupakan reaktor nuklir modular dengan daya $160 \mathrm{MWt}$ untuk satu modulnya. Saat ini, PWR Integral menggunakan bahan bakar $\mathrm{UO}_{2}$ sebagai bahan bakar utama. Penelitian ini bertujuan untuk mengetahui perubahan performa teras reaktor dari yang sebelumnya menggunakan bahan bakar $\mathrm{UO}_{2}$ menjadi bahan bakar MOX. Penelitian ini dilakukan dengan cara memvariasikan rasio $\mathrm{PuO}_{2}$ dalam bahan bakar MOX, jumlah bahan bakar, dan jenis kelongsong dengan menggunakan sistem kode SRAC2006. Studi parameter dilakukan dengan memperhatikan nilai $\mathrm{k}_{\mathrm{eff}}$, rasio konversi, dan jumlah aktinida, serta akan dilakukan pula perbandingan dengan teras reaktor yang menggunakan bahan bakar $\mathrm{UO}_{2}$. Hasil penelitian menunjukkan performa teras reaktor dengan bahan bakar MOX lebih baik daripada $\mathrm{UO}_{2}$. Desain teras PWR Integral yang paling optimum adalah teras dengan rasio $\mathrm{PuO}_{2}$ dalam $\mathrm{MOX} 12 \%$, diameter teras $165 \mathrm{~cm}$, dan jenis kelongsong Zircalloy-4. Hal ini dapat dilihat dari periode kekritisan teras reaktor yang mencapai 1521 hari dengan nilai $\mathrm{CR}$ paling rendah adalah 0,622004. Excess reactivity yang dimiliki juga lebih rendah yaitu 1,0745932 dimana desain $\mathrm{UO}_{2}$ bernilai 1,1035821. Aktinida yang dihasilkan mengalami tren penurunan seiring reaktor beroperasi.
\end{abstract}

Kata kunci: PWR Integral, MOX, $\mathrm{k}_{\mathrm{eff}}$, rasio konversi, inventori aktinida.

\section{ABSTRACT}

CORE DESIGN PARAMETRIC STUDY OF INTEGRAL PRESSURIZED WATER REACTOR (IPWR) WITH MIXED OXIDE CERAMIC FUEL USING SRAC CODE SYSTEM. Integral PWR using MOX fuel can be used as solution to handle electrification problem in archipelagic nations as well as to accomodate the transition of fuel from $\mathrm{UO}_{2}$ to $\mathrm{MOX}$. Integral PWR is a modular nuclear power plant with 160 $M W t$ for each module. Recently, Integral PWR use $\mathrm{UO}_{2}$ fuel as the main fuel. This research's purpose is to determine the change of reactor core performance from $\mathrm{UO}_{2}$ into $\mathrm{MOX}$. This research is done by varying PuO $\mathrm{O}_{2}$ ratio in MOX, number of fuel, and type of fuel cladding using SRAC2006 code system. Parametric study is

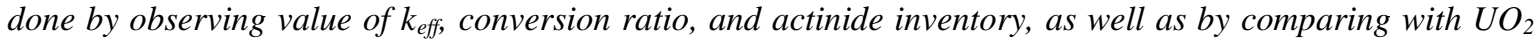
fuel reactor core. Result shows that performance of reactor core using $M O X$ is better than $\mathrm{UO}_{2}$ reactor core. The most optimum design of Integral PWR is using 12\% PuO2 in MOX fuel, core diameter $165 \mathrm{~cm}$, and Zircalloy-4 cladding. This can be observed from period of criticality of reactor core up to 1521 days with lowest $C R$ is 0,622004. Excess reactivity of this reactor core is lower than $\mathrm{UO}_{2}$ fuel design $(1,07745932$ compared with 1,1035821). Actinide produced by this core shows declining trend during reactor operation.

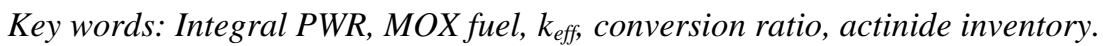




\section{PENDAHULUAN}

Perkembangan ekonomi di Indonesia mengakibatkan kebutuhan energi yang meningkat, utamanya dalam bentuk listrik. Namun, muncul masalah dari hal ini yaitu ketidakmerataan elektrifikasi di Indonesia. Berdasarkan data dari Kementerian ESDM pada tahun 2017, beberapa provinsi seperti NTT dan Papua memiliki rasio elektrifikasi kurang dari $60 \%$. Hal ini sangat timpang dengan kondisi di DKI Jakarta yang sudah teraliri listrik hingga 99,8\% [1].

Selain itu, dalam dunia ketenaganukliran, masalah limbah selalu menjadi perhatian. Saat ini terjadi penumpukan jumlah plutonium dalam spent fuel karena pengelolaannya yang langsung dibuang ke interim storage tanpa reprocessing. Penumpukan ini menjadi rentan karena plutonium yang dihasilkan dapat dimanfaatkan sebagai senjata nuklir [2].

Teknologi Small and Modular Reactor seperti PWR Integral dapat menjadi pilihan untuk mengatasi masalah elektrifikasi di Indonesia. PWR integral adalah jenis reaktor modular dengan daya 160 MWt. Bentuknya yang modular menjadikan pembuatan dari setiap komponen tidak harus dilakukan secara on-site. Dayanya yang kecil memberikan keleluasaan penggunaan energi yang dibutuhkan [3]. Dengan menggunakan teknologi reprocessing, plutonium dapat dijadikan bagian dari bahan bakar PWR integral dengan menjadi MOX [4].

Konsep dari PWR integral adalah menggabungkan seluruh komponen primer ke dalam satu bejana. Dengan menggunakan konsep ini, waktu konstruksi dapat dipercepat sehingga reaktor bisa semakin cepat digunakan [5].

Bahan bakar MOX merupakan bahan bakar hasil reprocessing dari bahan bahan nuklir bekas dari satu reaktor daya nuklir. Pada umumnya, dalam sebuah reaktor nuklir akan dihasilkan satu persen plutonium. Dari satu persen plutonium tersebut, dua per tiga bagian di antaranya merupakan isotop ${ }^{239} \mathrm{Pu}$ dan ${ }^{241} \mathrm{Pu}$ yang merupakan nuklida fisil. Dengan adanya ${ }^{239} \mathrm{Pu}$ dan ${ }^{241} \mathrm{Pu}$ dalam campuran bahan bakar, maka neutron yang diproduksi akan semakin banyak [6].

Penelitian ini bertujuan untuk mengetahui perubahan performa teras PWR Integral dari yang awalnya menggunakan bahan bakar $\mathrm{UO}_{2}$ menjadi bahan bakar MOX. Beberapa parameter yang dilakukan variasi adalah rasio $\mathrm{PuO}_{2}$ di dalam MOX, jumlah bahan bakar, dan jenis kelongsong yang digunakan. Perubahan performa ini diketahui dengan memperhatikan nilai $k_{\text {eff, }}$ rasio konversi, dan jumlah aktinida. Perhitungan dilakukan dengan kode SRAC2006 dan COREBN, sistem kode yang dikembangkan oleh JAEA untuk perhitungan neutronik pada reaktor termal [7] [8].

\section{METODE}

\section{Studi Pustaka}

Tahap awal dari pelaksanaan penelitian yang dilakukan adalah studi pustaka. Studi pustaka ini dilakukan untuk mengetahui informasi parameter-parameter teras yang saat ini sudah dilakukan proses perizinan oleh NuScale, LLC. Kegiatan ini dilakukan dengan melakukan pengumpulan referensi dan datadata penting yang akan menunjang kegiatan penelitian. Referensi dan data-data tersebut dapat diambil dari berbagai literatur. Literatur yang digunakan dalam penelitian ini mencakup beberapa topik yaitu informasi mengenai rancang bangun PWR Integral, konfigurasi teras yang saat ini digunakan di dalam PWR Integral, komposisi bahan bakar yang saat ini digunakan, informasi mengenai material yang akan digunakan dalam variasi, konfigurasi teras untuk tujuan pengembangan dan variasi, serta studi mengenai SRAC dan COREBN yang digunakan sebagi simulator.

\section{Perhitungan Data Nuklida}

Data nuklida didapatkan dari proses perhitungan yang dilakukan berdasarkan informasi teras reaktor yang didapatkan dari studi literatur desain teras yang sudah ada sebelumnya. Berdasarkan informasi tersebut, dilakukan perhitungan nuklida dan berbagai informasi yang belum diketahui. Informasi yang belum diketahui tersebut di antaranya adalah suhu gap, suhu kelongsong, densitas $\mathrm{UO}_{2}$, $\mathrm{PuO}_{2}, \mathrm{Gd}_{2} \mathrm{O}_{3}$, dan campuran $\mathrm{UO}_{2}-\mathrm{Gd}_{2} \mathrm{O}_{3}$ serta MOX. Informasi di atas sangat penting diketahui untuk melakukan perhitungan densitas nuklida dari material yang digunakan di dalam reaktor. 
Bagian selanjutnya yang harus dihitung adalah densitas nuklida. Rumus dasar yang digunakan untuk menghitung densitas nuklida adalah sebagai berikut:

$$
N=\frac{N_{\text {Av }} \cdot \rho_{\text {operasi }} \cdot 1 \times 10^{-24}}{M r_{\text {nuklida }}}
$$

Dalam desain benchmark, terdapat dua jenis bahan bakar yang digunakan. Kedua bahan bakar ini disusun menjadi dua jenis fuel assembly yang berbeda. Fuel assembly (FA) yang pertama berisi bahan bakar $\mathrm{UO}_{2}$ murni dengan pengayaan $4,05 \%$. Di dalam FA kedua terkandung juga $\mathrm{Gd}_{2} \mathrm{O}_{3}$ pada pin bahan bakar. Pada desain NuScale, kandungan $\mathrm{Gd}_{2} \mathrm{O}_{3}$ dapat berkisar hingga $8 \%$. Namun, pada penelitian ini digunakan nilai kandungan $\mathrm{Gd}_{2} \mathrm{O}_{3}$ sebesar $6,5 \%$. Nilai ini didapatkan berdasarkan informasi dari penelitian-penelitian sebelumnya yang menggunakan bahan bakar campuran $\mathrm{UO}_{2}-\mathrm{Gd}_{2} \mathrm{O}_{3}$. Pada penelitian-penelitian sebelumnya, kandungan $\mathrm{Gd}_{2} \mathrm{O}_{3}$ rata-rata sebesar $3,25 \%$. Pada penelitian ini, diasumsikan kandungan $\mathrm{Gd}_{2} \mathrm{O}_{3}$ sebesar dua kali kandungan rata-rata $\mathrm{Gd}_{2} \mathrm{O}_{3}$ untuk mengompensasi kemungkinan prompt jump yang signifikan. Pada desain NuScale, $\mathrm{Gd}_{2} \mathrm{O}_{3}$ terdapat pada 32 pin saja. Namun untuk mempermudah desain, $\mathrm{Gd}_{2} \mathrm{O}_{3}$ diasumsikan tersebar merata.

\section{Pembuatan Desain Benchmark}

Proses desain selanjutnya adalah pembuatan desain teras benchmark yang mencakup fuel assembly, reflektor, moderator, dan ruang untuk batang kendali. Fuel assembly berbentuk persegi dengan ukuran array 17x17 pin. Ruang untuk batang kendali dimodelkan berisi dengan air karena batasan masalah yang tidak memperhitungkan batang kendali. Sebaran ruang untuk batang kendali disesuaikan dengan desain yang sudah ada dari NuScale Reactor.

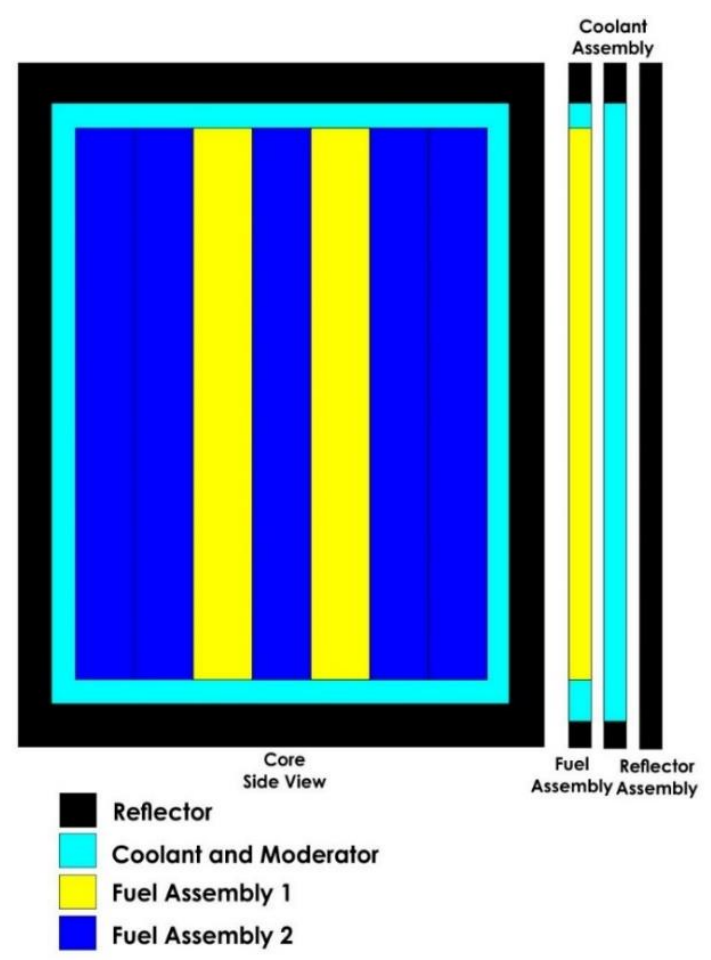

Gambar. 1. Gambar teras reaktor dari sisi samping
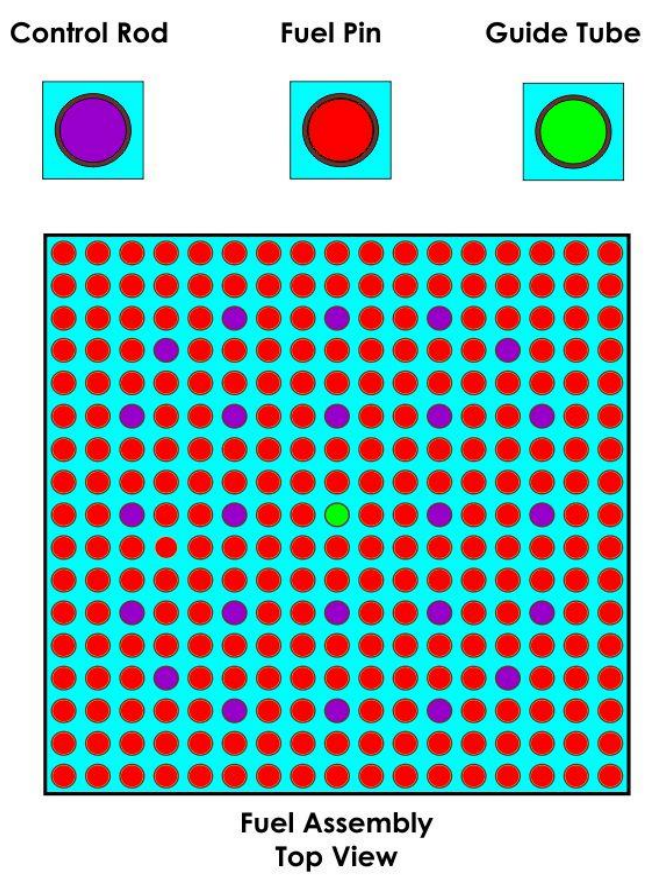

Gambar. 2. Gambar fuel assembly dari sisi atas 


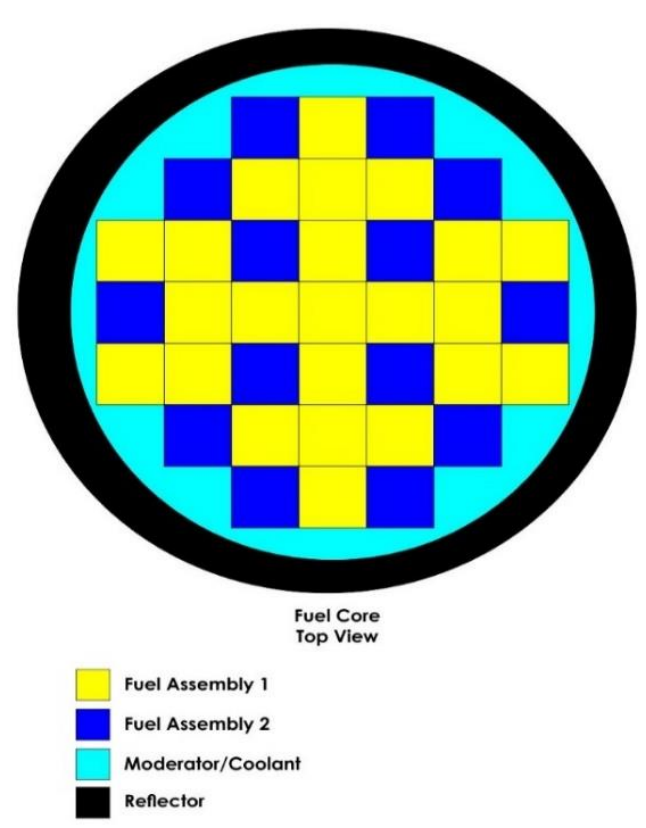

Gambar. 3. Gambar teras reaktor dari sisi atas

Setelah geometri teras telah dipastikan dan semua data telah didapatkan, dilakukan proses pemodelan teras reaktor menggunakan kode simulasi SRAC dan COREBN, proses koding dilakukan dengan menggunakan perangkat lunak AcroEdit. Format kode yang dimasukkan ke dalam SRAC dan COREBN disesuaikan dengan format yang tersedia untuk SRAC dan COREBN. Teras reaktor pada mulanya digambarkan sebagai sebuah fuel assembly yang kemudian diperbesar menjadi satu teras.

Untuk menggambarkan fuel assembly dari teras reaktor, digunakan kode input SRAC PIJ (collision probability method) dimana kode input ini akan menentukan tambang lintang mikroskopis efektif yang merupakan hasil homogenisasi dari fuel assembly. Untuk menggambarkan teras reaktor yang terdiri dari sekumpulan fuel assembly tanpa melakukan perhitungan burn-up, digunakan modul CITATION dari SRAC yang mampu memodelkan teras yang tersusun atas assembly yang berbentuk persegi dengan pemodelan 3D cartesian (X-Y-Z). Dari pemodelan ini, didapatkan nilai $\mathrm{k}_{\text {eff }}$ dari konfigurasi teras reaktor benchmark.

Setelah dilakukan nilai $\mathrm{k}_{\text {eff }}$ dari konfigurasi teras, dilakukan pemodelan teras untuk melihat performa teras saat beroperasi pada mode burnup (time dependent calculation). Tahapan pemodelan yang dilakukan untuk mode burnup dimulai dengan pembuatan tabel tampang lintang yang sebelumnya telah dibuat oleh PIJ. Kemudian tabel tersebut dilengkapi dengan informasi densitas nuklida dan informasi lain yang dibutuhkan oleh kode input COREBN. Untuk mendaftarkan informasi fuel assembly dan assembly lain yang digunakan di dalam teras, kode HIST juga dibuat. Di dalam kode input COREBN juga terdapat pengembangan kode CITATION yang berfungsi untuk menunjukkan posisi masing-masing assembly yang terdapat di dalam teras, daya operasi reaktor, waktu perhitungan burnup yang diinginkan, dan kriteria-kriteria perhitungan lainnya yang membuat perhitungan menjadi lebih efektif. Dalam pemodelan menggunakan COREBN ini, didapatkan nilai $\mathrm{k}_{\text {eff }}$ dari teras reaktor, conversion ratio (CR), fluks neutron pada masing-masing assembly, distribusi daya aksial dan radial sebagai fungsi waktu, dan informasi inventori aktinida bahan bakar di awal dan akhir simulasi.

\section{Variasi Desain Teras Reaktor}

Setelah didapatkan performa teras reaktor benchmark dari hasil simulasi SRAC dan COREBN, dilakukan pemodelan lebih lanjut dalam berbagai variasi parameter. Perubahan parameter dilakukan dengan mengubah kode input yang disesuaikan dengan variasi yang sedang ditinjau. Kode SRAC diubah sehingga tabel tampang lintang diubah diikuti kode input HIST yang mendaftarkan assembly dan kode COREBN yang digunakan dalam teras reaktor. Sedangkan pada variasi jumlah bahan bakar dan tebal reflektor, kode input HIST dan COREBN diubah dengan tidak mengubah kode SRAC karena tabel yang digunakan masih sama.

Pada variasi rasio $\mathrm{PuO}_{2}$ dalam MOX, variasi yang digunakan adalah sebagai berikut,

Tabel. 1. Variasi rasio $\mathrm{PuO}_{2}$ dalam MOX

\begin{tabular}{ccccr}
\hline $\begin{array}{c}\text { Rasio } \\
\mathrm{PuO}_{2} \\
\text { dalam } \\
\text { MOX (\%) }\end{array}$ & \multicolumn{2}{c}{$\begin{array}{c}\text { Nomor Massa } \\
\text { MOX (g/mol) }\end{array}$} & \multicolumn{2}{c}{ Massa Jenis $\left(\mathrm{g} / \mathbf{c m}^{3}\right)$} \\
\cline { 2 - 5 } & $\boldsymbol{F A ~ 1 ~}$ & $\boldsymbol{F A ~ 2}$ & FA 1 & FA 2 \\
\hline 8 & 270,166 & 270,895 & 10,559 & 10,518 \\
\hline 10 & 270,200 & 270,929 & 10,568 & 10,527 \\
\hline 12 & 270,234 & 270,963 & 10,577 & 10,536 \\
\hline 14 & 270,269 & 270,998 & 10,586 & 10,546 \\
\hline 16 & 270,303 & 271,032 & 10,596 & 10,555 \\
\hline
\end{tabular}

Pada variasi jumlah bahan bakar, massa bahan bakar dibuat konstan. Sehingga variasi yang dilakukan adalah variasi jumlah dan tinggi FA di dalam teras dengan melakukan perubahan 
diameter teras reaktor. Variasi yang digunakan adalah sebagai berikut,

Tabel. 2. Variasi diameter teras

\begin{tabular}{cccc}
\multirow{2}{*}{$\begin{array}{c}\text { Diameter } \\
\text { Teras }(\mathbf{c m})\end{array}$} & $\begin{array}{c}\text { Tinggi Teras } \\
(\mathbf{c m})\end{array}$ & \multicolumn{2}{c}{ Jumlah FA } \\
\cline { 3 - 4 } & & FA 1 & FA 2 \\
\hline 115 & 569,077 & 9 & 4 \\
\hline 140 & 352,128 & 17 & 4 \\
\hline 165 & 200,000 & 23 & 14 \\
\hline 190 & 164,402 & 31 & 14 \\
\hline 215 & 121,319 & 37 & 24 \\
\hline
\end{tabular}

Pada variasi jenis kelongsong, variasi yang digunakan adalah sebagai berikut,

Tabel. 3. Variasi jenis kelongsong

\begin{tabular}{|c|c|c|}
\hline Jenis Kelongsong & $\begin{array}{l}M r_{\text {kelongsong }} \\
(\mathrm{g} / \mathrm{mol})\end{array}$ & $\begin{array}{c}\text { Densitas } \\
\text { Kelongsong }\left(\mathrm{g} / \mathrm{cm}^{3}\right)\end{array}$ \\
\hline Zircalloy-4 & 91,52402696 & 6,55089 \\
\hline SS 316 & 56,30490907 & 7,99 \\
\hline SS 410 & 56,25494474 & 7,74 \\
\hline Zr-2,5\%Nb Alloy & 91,19707 & 6,57 \\
\hline
\end{tabular}

Dengan menggunakan variasi di atas, simulasi dilakukan dengan menggunakan SRAC dan COREBN.

Analisis dan pengolahan data dilakukan dengan menganalisis hasil keluaran dari SRAC dan COREBN dalam suatu perangkat lunak pengolah data.

\section{HASIL DAN PEMBAHASAN}

\section{Desain Awal Teras Reaktor PWR Integral Menggunakan $\mathrm{UO}_{2}$}

Desain awal yang digunakan dalam penelitian ini dapat dilihat dalam tabel sebagai berikut,

Tabel. 4. Properti dari desain awal PWR Integral

\begin{tabular}{|c|c|c|}
\hline Properti & Unit & Besaran \\
\hline \multicolumn{3}{|c|}{ Core } \\
\hline Radius & $\mathrm{cm}$ & 82,5 \\
\hline Jumlah assembly & - & 37 \\
\hline Daya termal reaktor & MW & 160 \\
\hline \multicolumn{3}{|c|}{ Fuel Assembly } \\
\hline Tipe bahan bakar & - & $\mathrm{UO}_{2}$ \\
\hline Pengayaan ${ }^{235} U$ & - & $4,05 \%$ dan $4,55 \%$ \\
\hline Model assembly & - & $\begin{array}{c}\text { Square Array } \\
17 \times 17 \text { pin }\end{array}$ \\
\hline Jumlah fuel rod dalam FA & - & 264 \\
\hline Jumlah Control Rod dalam FA & - & 24 \\
\hline $\begin{array}{l}\text { Jumlah Instrumentation Tube } \\
\text { dalam FA }\end{array}$ & - & 1 \\
\hline
\end{tabular}

\begin{tabular}{lcc}
\hline Tebal Struktur FA & $\mathrm{cm}$ & 0,04 \\
\hline Bahan struktur & - & SS 304L \\
\hline Pitch FA & $\mathrm{cm}$ & 21,50364 \\
\hline Bahan pendingin & Fuel Rod & $\mathrm{H}_{2} \mathrm{O}$ \\
\hline & $\mathrm{cm}$ & 0,94996 \\
\hline Diameter Luar Kelongsong & $\mathrm{cm}$ & 0,82804 \\
\hline Diameter Dalam Kelongsong & $\mathrm{cm}$ & 0,01651 \\
\hline Tebal Gap & $\mathrm{cm}$ & 0,81153 \\
\hline Diameter Bahan Bakar & - & Helium \\
\hline Material Gap & - & Zircalloy-4 \\
\hline Material Kelongsong & $\mathrm{cm}$ & 1,25984 \\
\hline Fuel Rod Pitch & $\mathrm{cm}$ & 200 \\
\hline Tinggi Fuel Rod & Reflektor & 14 \\
\hline Binggi reflektor aksial atas/bawah & $\mathrm{cm}$ & \\
\hline Tebal reflektor radial & & SS 304L \\
\hline
\end{tabular}

\begin{tabular}{lcc}
\hline \multicolumn{3}{c}{ Parameter Termal Hidraulik } \\
\hline Tekanan & psia & 1450 \\
\hline Suhu rata-rata fuel pin & K & 772,039 \\
\hline Suhu rata-rata gap & K & 739,2094 \\
\hline Suhu rata-rata moderator & K & 645,5721697 \\
\hline Suhu rata-rata kelongsong & K & 557,039 \\
\hline Suhu rata-rata reflektor & K & 557,039
\end{tabular}

Dengan menggunakan desain yang didasarkan pada parameter di atas, didapatkan nilai $k_{\text {eff }}$ yang memiliki nilai lebih besar daripada 1. Nilai burnup ini dapat diturunkan hingga bernilai sama dengan 1 (kritis) atau bahkan kurang dari 1 (subkritis) dengan cara menambahkan Control Rod dan racun penyerap neutron.

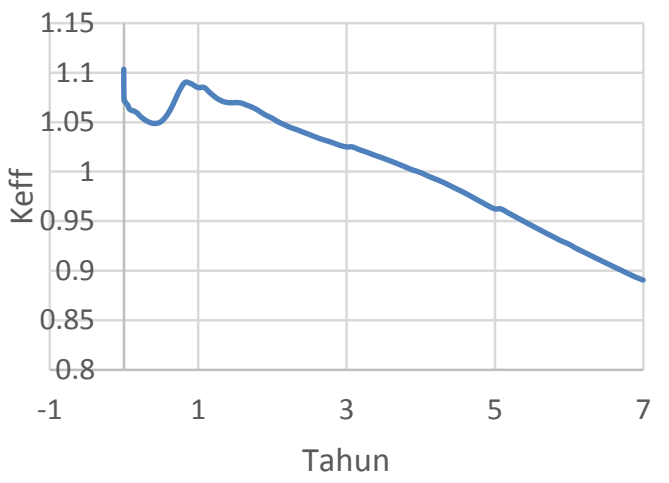

Gambar. 4. Nilai $\mathrm{k}_{\text {eff }}$ teras desain awal selama operasi reaktor 
Desain teras benchmark ini dapat beroperasi sesuai dengan kriteria kekritisan hingga 1425,75 hari. Pada periode awal operasi reaktor, terjadi proses penurunan yang signifikan akibat produksi racun neutron Xenon dan Samarium yang sangat memengaruhi populasi neutron di dalam teras reaktor. Produksi Xenon dan Samarium kemudian berangsur-angsur stabil hingga menuju titik kesetimbangannya. Selain Xenon dan Samarium, juga terdapat efek serapan neutron dari gadolinia yang terkandung di dalam 14 FA di teras reaktor.

Xenon dan Samarium yang sudah setimbang kemudian dibarengi oleh proses fisi yang terus menerus di dalam reaktor yang superkritis sehingga menyebabkan adanya kenaikan kritikalitas teras reaktor. Puncak kritikalitas teras reaktor mencapai puncaknya ketika bahan fisil masih tersedia cukup banyak sehingga mampu mengatasi pertumbuhan bahan fertil akibat transmutasi maupun bahan yang diproduksi akibat produk fisi. Setelah kondisi ini, kritikalitas teras benchmark berangsurangsur semakin berkurang dengan laju yang relatif konstan.

Selain perubahan nilai kritikalitas dalam teras, rasio banyaknya nuklida fisil dan fertil juga berubah seiring berjalannya waktu. Rasio banyaknya nuklida fisil dan nuklida fertil digambarkan melalui parameter rasio konversi (Conversion Ratio/CR). Fenomena rasio konversi yang terjadi di dalam teras digambarkan melalui grafik sebagai berikut,

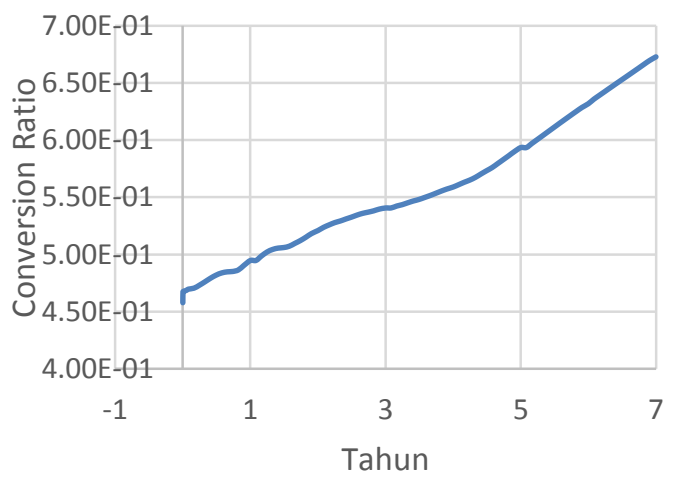

Gambar. 5. Nilai rasio konversi desain awal teras reaktor selama periode operasi reaktor

Pada rasio konversi, didapatkan fenomena dimana nilai CR semakin lama semakin bertambah. Pada periode awal operasi teras reaktor, dapat dilihat bahwa nilai $\mathrm{CR}$ yang dihasilkan bernilai 0,457805 dan terus meningkat hingga bernilai 0,672904 pada tahun ketujuh. Pada lima tahun operasi reakor, teras benchmark ini bersifat sebagai pembakar (burner). Hal ini dikarenakan nilai CR yang dihasilkan lebih rendah daripada 0,6. Pada tahun kelima hingga akhir operasi reaktor, teras reaktor bersifat sebagai converter. Namun, perlu diperhatikan bahwa ketika nilai $\mathrm{CR}$ yang dihasilkan cukup baik, teras reaktor berada dalam fase subkritis. Hal ini menunjukkan meskipun konsumsi bahan bakar fisil memiliki rasio yang lebih rendah dibandingkan periode awal teras reaktor, bahan bakar fisil tersebut tidak mampu untuk menyediakan neutron yang cukup sehingga teras menjadi kritis ataupun superkritis.

Inventori aktinida merupakan parameter lain yang dapat diperhatikan untuk melihat bagaimana perilaku teras reaktor dalam mengonsumsi bahan bakar yang ada dan memproduksi bahan bakar yang baru. Pada penelitian ini dibatasi hanya pada tujuh nuklida saja yang diamati yaitu ${ }^{235} \mathrm{U},{ }^{236} \mathrm{U},{ }^{238} \mathrm{U},{ }^{239} \mathrm{Pu}$, dan ${ }^{240} \mathrm{Pu}$. Distribusi dari ketujuh nuklida tersebut seiring operasi reaktor ditampilkan pada Tabel 5,

Tabel. 5. Jumlah aktinida yang dihasilkan oleh desain awal teras reaktor

\begin{tabular}{cccccc} 
Tahun & \multicolumn{5}{c}{ Aktinida (gram) } \\
\hline & ${ }^{235} \boldsymbol{U}$ & ${ }^{236} \boldsymbol{U}$ & ${ }^{238} \boldsymbol{U}$ & ${ }^{239} \mathrm{Pu}$ & ${ }^{240} \mathrm{Pu}$ \\
\hline 0 & 390.170 & 8.930 .100 & 0 & 0 & 0 \\
\hline 1 & 334.300 & 8.895 .500 & 21.006 & 2.309 & 865,22 \\
\hline 3 & 242.380 & 8.819 .700 & 43.225 & $9.752,7$ & $5.417,8$ \\
\hline 5 & 167.840 & 8.740 .200 & 54.287 & 16.925 & 10.355 \\
\hline 7 & 111.200 & 8.653 .500 & 58.788 & 22.998 & 14.632 \\
\hline & Berdasarkan tabel & di atas, didapatkan
\end{tabular}

informasi bahwa terjadi penambahan jumlah ${ }^{239} \mathrm{Pu}$ dan juga pengurangan jumlah ${ }^{238} \mathrm{U}$. Pengurangan jumlah ${ }^{238} \mathrm{U}$ dapat dijelaskan karena konsumsi bahan bakar reaktor seiring berjalannya waktu. Penambahan ${ }^{239} \mathrm{Pu}$ merupakan hasil transmutasi yang terjadi akibat reaksi serapan di dalam teras reaktor. Konsumsi ${ }^{235} \mathrm{U}$ dan ${ }^{238} \mathrm{U}$ pada tahun pertama operasi teras reaktor dapat dikatakan signifikan. Hal ini dapat disebabkan oleh nilai rasio konversi teras pada periode awal operasi teras yang berkisar antara 0,4 hingga 0,5 sehingga begitu banyak bahan bakar yang dikonsumsi. Kemudian, nilai tersebut cenderung turun secara stabil pada 
tahun ketiga hingga ketujuh. Nilai dari ${ }^{239} \mathrm{Pu}$ sendiri mengalami kenaikan terus menerus dengan laju yang relatif konstan.

Hasil dari desain di atas dijadikan acuan untuk melakukan analisis pada variasi yang akan dilakukan. Variasi-variasi yang dilakukan juga akan mempertimbangkan parameter utama seperti $\mathrm{k}_{\text {eff, }} \mathrm{CR}$, densitas daya aksial, dan inventori aktinida yang dihasilkan selama operasi teras reaktor.

\section{Variasi Rasio $\mathrm{PuO}_{2}$ di dalam Bahan Bakar MOX}

Variasi rasio $\mathrm{PuO}_{2}$ di dalam bahan bakar MOX dilakukan dengan mengubah jumlah nuklida yang dari material yang digunakan untuk menyusun bahan bakar MOX. Bahan bakar MOX yang digunakan adalah bahan bakar $\mathrm{PuO}_{2}-\mathrm{UO}_{2}$ dan $\mathrm{PuO}_{2}-\mathrm{UO}_{2}-\mathrm{Gd}_{2} \mathrm{O}_{3}$ yang dicampurkan secara homogen. Kandungan isotop plutonium yang menyusun bahan bakar MOX dibuat konstan dengan pembagian sebagai berikut,

Tabel. 6. Komposisi plutonium pada $\mathrm{PuO}_{2}$

\begin{tabular}{cc} 
Komposisi Plutonium & Persentase (\%) \\
\hline${ }^{238} \mathrm{Pu}$ & 4,6 \\
\hline${ }^{239} \mathrm{Pu}$ & 50,5 \\
\hline${ }^{240} \mathrm{Pu}$ & 24 \\
\hline${ }^{241} \mathrm{Pu}$ & 12,5 \\
\hline${ }^{242} \mathrm{Pu}$ & 8,4
\end{tabular}

Setelah dilakukan perhitungan dan diterapkan pada kode SRAC dan COREBN, didapatkan hasil perhitungan $\mathrm{k}_{\text {eff }}$ sebagai berikut,

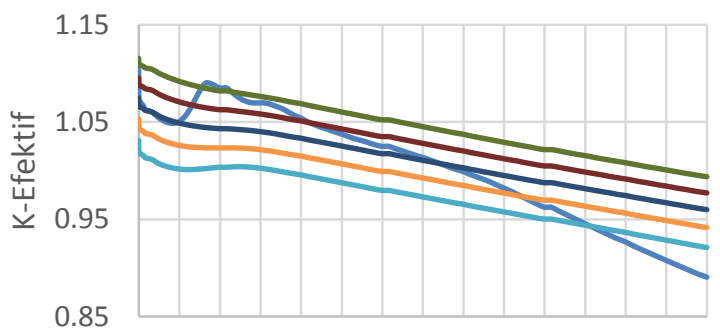

00.511 .522 .533 .544 .555 .566 .57 Tahun

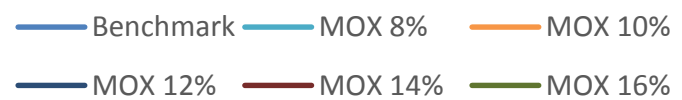

Gambar. 6. Nilai keff selama operasi reaktor pada variasi rasio $\mathrm{PuO} 2$ dalam $\mathrm{MOX}$
Pada variasi yang telah ditunjukkan pada grafik di atas, diketahui bahwa variasi varfuel2 $\left(\mathrm{PuO}_{2} 2 \%\right.$ dalam $\left.\mathrm{MOX}\right)$ dan varfuel4 $\left(\mathrm{PuO}_{2} 4 \%\right.$ dalam MOX) selalu bernilai kurang dari 1 sejak awal operasi reaktor. Hal ini dapat dijelaskan karena jumlah nuklida fisil di dalam variasi tersebut tidak cukup untuk membuat teras berada dalam kondisi kritis. Jumlah neutron yang dihasilkan oleh teras reaktor masih terlalu kecil bila dibandingkan dengan serapan neutron yang terjadi. Pada variasi selanjutnya, nilai awal operasi reaktor semakin lama semakin tinggi. Nilai paling tinggi dihasilkan oleh varfuel20 $\left(\mathrm{PuO}_{2} \quad 20 \%\right.$ dalam MOX) dengan nilai 1,1545849. Nilai ini merupakan nilai pada variasi rasio $\mathrm{PuO}_{2}$ dalam MOX yang tertinggi, sehingga nilai ini dapat disebabkan oleh banyaknya nuklida fisil yang terkandung di dalam bahan bakar.

Pada variasi $2 \%$ hingga $8 \%$ dapat dilihat bahwa terjadi penurunan nilai kritikalitas di periode awal operasi teras reaktor seperti halnya yang terjadi pada teras benchmark. Hal ini menunjukkan pengaruh Xenon, Samarium, dan gadolinia masih cukup signifikan di dalam kritikalitas teras reaktor. namun, hal ini tidak terjadi pada variasi $10 \%$ hingga 20\% karena nuklida fisil yang dihasilkan bersumber plutonium yang memiliki nilai $v$ yang besar. Nilai $v$ ini mengompensasi pengaruh gadolinia di dalam teras reaktor sehingga kurva yang dihasilkan menjadi turun secara konstan.

Dari hasil grafik di atas, dapat disimpulkan kemampuan teras reaktor untuk mampu bertahan menjaga kekritisannya dalam waktu yang berbeda-beda. Periode kekritisan dari masing-masing variasi ditunjukkan melalui tabel berikut,

Tabel. 7. Periode kekritisan yang dihasilkan oleh variasi rasio $\mathrm{PuO}_{2}$ dalam MOX

\begin{tabular}{cc}
\hline Kandungan $\mathrm{PuO}_{2}(\%)$ & \multicolumn{2}{c}{ Periode Kekritisan (hari) } \\
\hline 8 & 605,8 \\
\hline 10 & 1060,5 \\
\hline 12 & 1521 \\
\hline 14 & 1946,25 \\
\hline 16 & 2371,5 \\
\hline
\end{tabular}

Secara umum, dapat dilihat bahwa penambahan rasio $\mathrm{PuO} 2$ di dalam teras reaktor akan secara signifikan menambah periode kekritias teras reaktor. perubahan ini dapat dilihat secara signifikan pada variasi $6 \%$ ke 
variasi $8 \%$ dimana terjadi perubahan periode kekritisan teras reaktor secara signifikan dengan selisih sekitar 604 hari. Pada variasi selanjutnya, perubahan yang terjadi rata-rata berselisih sekitar 400 hari. Pada variasi $18 \%$ dan $20 \%$ perubahannya tidak dapat diperlihatkan karena sudah melewati periode yang sudah ditentukan dalam COREBN.

Rasio $\mathrm{PuO}_{2}$ ini juga menyebabkan adanya perubahan fenomena dalam rasio konversi. Perubahan yang terjadi di dalam teras reaktor digambarkan melalui grafik sebagai berikut,

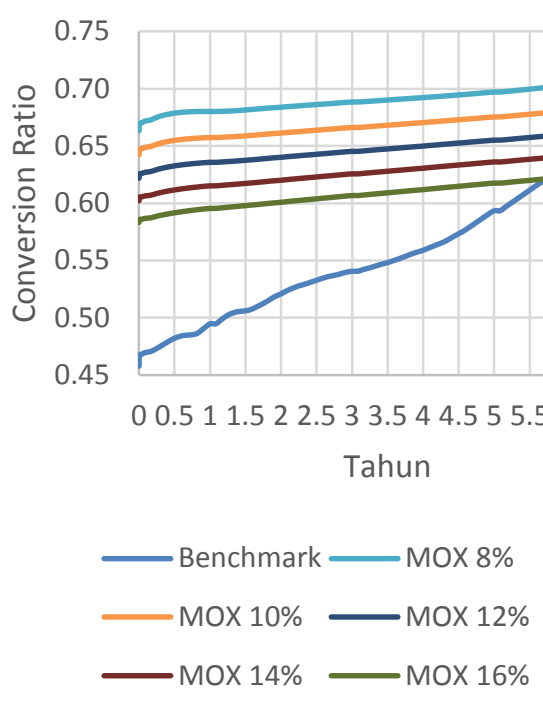

Gambar. 7. Nilai rasio konversi selama operasi raktor pada variasi rasio $\mathrm{PuO}_{2}$ dalam MOX

Fenomena yang berkebalikan dengan $\mathrm{k}_{\text {eff }}$ terjadi pada rasio konversi. Pada variasi $2 \%$ $\mathrm{PuO}_{2}$ dalam MOX, nilai rasio konversi menjadi yang paling tinggi. Hal ini berarti kemampuan bahan bakar untuk mengkonversi menjadi material fisil menjadi lebih baik. Namun, hal itu tidak diimbangi dengan konsumsi bahan bakar karena jumlah neutron yang diproduksi tidak cukup untuk membuat teras menjadi kritis. Semakin tinggi nilai $\mathrm{PuO}_{2}$ dalam $\mathrm{MOX}$, maka nilai CR menjadi semakin kecil meskipun seluruh variasi menunjukkan tren kenaikan yang sama seiring berjalannya waktu. Meskipun begitu, variasi teras hanya menghasilkan reaktor yang bertipe converter.

Dengan menggunakan nilai kritikalitas dan rasio konversi, maka dipilihlah variasi varfuel12 yang memiliki rasio $\mathrm{PuO} 2$ sebesar $12 \%$ di dalam MOX. Nilai ini dipilih karena periode kritikalitas teras varfuel12 dapat melebihi benchmark, nilai excess reactivity yang juga lebih kecil dari teras benchmark, dan juga CR yang dimiliki masih berada di rentang yang sama dengan reaktor PWR pada umumnya (sekitar 0,6). Selain itu, nilai ini masih tidak jauh melebihi rasio $\mathrm{PuO} 2$ di dalam bahan bakar MOX yang digunakan pada umumnya yaitu $7 \%$ hingga $11 \%$.

\section{Variasi Jumlah Bahan Bakar}

Variasi jumlah bahan bakar dilakukan dengan melakukan variasi pada jumlah fuel Assembly dan tinggi dari teras reactor dan dengan mempertahankan massa bahan bakar selama variasi dilakukan. Massa bahan bakar yang telah dihitung adalah 10.672.499,9020841 gram. Nilai ini kemudian disesuaikan dengan variasi diameter teras reaktor. Variasi diameter teras reaktor kemudian akan menyesuaikan tinggi teras reaktor. Besaran baru bernama rasi $\mathrm{H} / \mathrm{D}$ atau rasio tinggi teras terhadap diameter juga akan berubah seiring dengan perubahan yang terjadi pada variasi ini. Variasi diameter dan tinggi teras yang sudah dihitung adalah sebagai berikut,

Tabel. 8. Nilai diameter, tinggi, dan H/D dari variasi jumlah bahan bakar

\begin{tabular}{cccc}
\hline $\begin{array}{c}\text { Diameter } \\
(\mathbf{c m})\end{array}$ & $\begin{array}{c}\text { Tinggi } \\
\mathbf{( c m})\end{array}$ & $\begin{array}{c}\text { Diameter/ } \\
\text { Tinggi }\end{array}$ & $\begin{array}{c}\text { Buckling } \\
\text { Geometri }\end{array}$ \\
\hline 115 & 569,076 & 4,949 & $1,996 \mathrm{E}-03$ \\
\hline 140 & 352,127 & 2,515 & $1,427 \mathrm{E}-03$ \\
\hline 165 & 200,000 & 1,212 & $1,097 \mathrm{E}-03$ \\
\hline 190 & 164,402 & 0,865 & $8,876 \mathrm{E}-04$ \\
\hline 215 & 121,319 & 0,564 & $7,473 \mathrm{E}-04$ \\
\hline
\end{tabular}

Nilai-nilai hasil perhitungan di atas dijadikan sebagai informasi dasar untuk melakukan perbaikan terhadap kode SRAC dan COREBN. Dengan menggunakan kode untuk variasi jumlah bahan bakar, didapatkan informasi sebagai berikut,
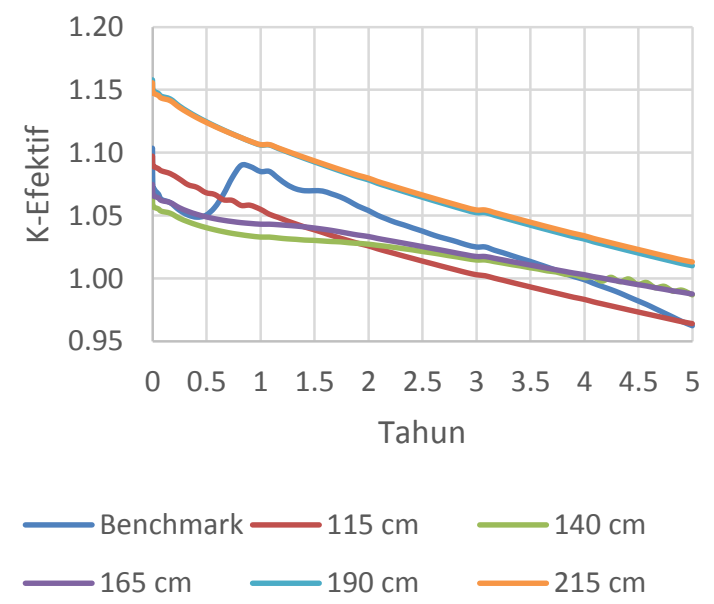

Gambar. 8. Nilai keff selama periode operasi reaktor dalam variasi jumlah bahan bakar 
Hasil dari perhitungan di atas menunjukkan pada variasi diameter $115 \mathrm{~cm}$, $140 \mathrm{~cm}$, dan $160 \mathrm{~cm}$ nilai kekritisan teras reaktor secara berurutan bernilai lebih kecil. Secara berurutan, periode kekritisan dari masing-masing teras reaktor adalah 1155,75 hari, 1491 hari, dan 1521 hari. Hal ini dapat disebabkan oleh turunnya nilai buckling geometri yang menyebabkan adanya penurunan nilai buckling material yang akan berpengaruh pada kriteria kekritisan yang perlu dicapai oleh teras reaktor. Kebocoran neutron karena pengaruh arah radial menjadi penting untuk diperhatikan karena sangat memengaruhi populasi teras reaktor. Hal yang unik terjadi pada variasi diameter $140 \mathrm{~cm}$ dimana setelah reaktor menjadi subkritis pada 1491 hari, pada hari ke-1551 teras sempat kembali kritis sebentar lalu kembali menjadi subkritis dalam periode 30 hari. Hal ini mungkin dapat terjadi karena adanya fluktuasi fluks neutron di dalam teras reaktor akibat nilai buckling geometri.

Namun, hal yang sebaliknya justru terjadi pada variasi diameter teras $190 \mathrm{~cm}$ dan $215 \mathrm{~cm}$. Periode kekritisan teras reaktor bernilai lebih dari 5 tahun dengan nilai kekritisan tertinggi masing-masing adalah 1,1578549 dan 1,1557086. Hal ini dapat disebabkan oleh bertambahnya jumlah fuel Assembly dari teras reaktor. Meskipun tinggi dari FA ini tidak setinggi sebelumnya, namun adanya penambahan FA ini tentunya akan berpengaruh pada fluks neutron yang ada di dalam teras reaktor tersebut. Adanya pengaruh pada fluks neutron akan memengaruhi kekritisan teras reaktor. Meskipun kebocoran neutron dari arah aksial (atas dan bawah) tidak bisa dihindarkan, namun nampaknya pada variasi ini jumlah FA yang bertambah menjadi faktor yang mendominasi terjadi perubahan pada variasi $190 \mathrm{~cm}$ dan $165 \mathrm{~cm}$. Berdasarkan hasil simulasi, didapatkan informasi bahwa nilai kekritisan tertinggi dari variasi diameter teras $190 \mathrm{~cm}$ dan $215 \mathrm{~cm}$ lebih tinggi daripada teras benchmark. Perbedaannya cukup signifikan mengingat nilai kekritisan tertinggi dan teras benchmark sebesar 1,1035821. Hal ini menjadi penting untuk menentukan variasi mana yang bisa dipilih untuk melakukan variasi selanjutnya.

Dari sisi parameter teras yang lain, hasil dari rasio konversi pada variasi ini ditunjukkan melalui gambar berikut,
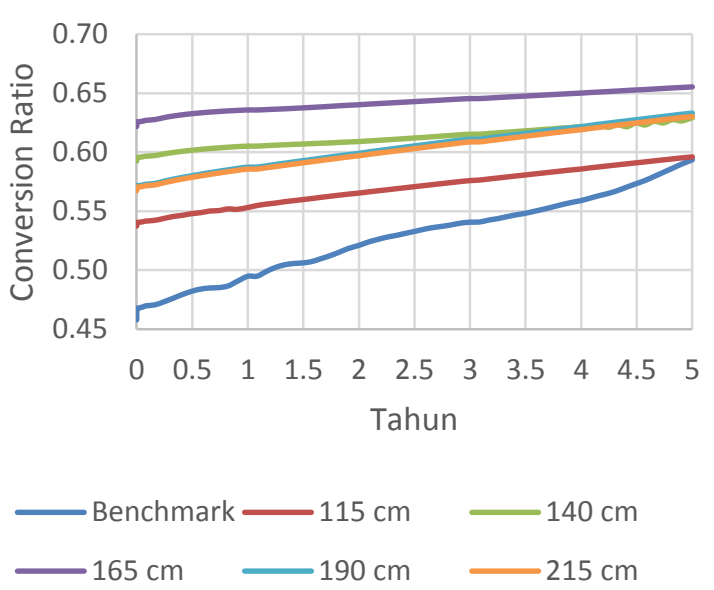

Gambar. 9. Nilai rasio konversi selama operasi reaktor dalam variasi jumlah bahan bakar

Variasi jumlah bahan bakar memberikan pengaruh yang cukup signifikan pada rasio konversi dari teras reactor. Variasi diameter 115 $\mathrm{cm}, 140 \mathrm{~cm}$, dan $160 \mathrm{~cm}$ memberikan nilai yang makin lama makin naik. Hal ini dapat dijelaskan karena bertambahnya jumlah bahan bakar di dalam teras reaktor. Bertambahnya jumlah bahan bakar akan berpengaruh terhadap jumlah bahan bakar yang melakukan transmutasi yang kemudian akan berpengaruh terhadap seberapa banyak proses konversi yang terjadi dari bahan bakar yang bersifat fertil menjadi bahan bakar yang bersifat fisil.

Namun, hal yang sebaliknya terjadi pada variasi selanjutnya. Efek yang berbalik dari $\mathrm{k}_{\mathrm{eff}}$ terjadi pada rasio konversi. Adanya perubahan tinggi yang signifikan memengaruhi bagaimana proses transmutasi terjadi di dalam teras reaktor. Dalam hal ini, penambahan jumlah FA dengan konsekuensi penurunan tinggi teras reaktor memperkecil kemampuan transmutasi teras reaktor dimana bahan bakar yang akan tertransmutasi tidak berubah dari material fertil menjadi material fisil karena neutron yang seharusnya menumbuk bahan bakar fertil tersebut justru sudah bocor keluar reaktor sebelum proses transmutasi terjadi. Pada hal ini, pengaruh kebocoran neutron secara aksial menjadi faktor yang dominan memengaruhi bagaimana perilaku teras reaktor.

Dengan menggunakan informasi yang sudah diperoleh, maka diputuskan variasi dengan diameter teras $165 \mathrm{~cm}$ untuk variasi selanjutnya. Variasi ini dipilih karena nilai kekritisan tertinggi yang dimiliki tidak lebih tinggi dari teras benchmark dan periode 
kekritisan yang dimiliki lebih tinggi dari teras benchmark. Hal ini baik dan diperlukan untuk keselamatan teras reaktor dalam hal excess reactivity yang harus diatasi oleh bahan penyerap neutron. Selain itu, dapat dilihat juga bahwa variasi diameter teras $165 \mathrm{~cm}$ memiliki nilai rasio konversi yang lebih baik daripada teras benchmark dan variasi yang lain.

\section{Variasi Jenis Kelongsong}

Pada variasi ini digunakan empat jenis kelongsong yang merupakan jenis zirconiumbased alloy dan stainless steel. Material zirconium-based alloy yang digunakan adalah zircalloy-4 dan $\mathrm{Zr}-2,5 \% \mathrm{Nb}$ Alloy, sementara material stainless steel yang digunakan adalah D9 dan HT9.

Zircalloy-4 merupakan material yang sangat umum digunakan sebagai material kelongsong. Hal ini dikarenakan kemampuannya yang dapat menahan panas radiasi karena sifat termofisikanya yang baik, dan juga karena memiliki tampang lintang serapan yang relatif kecil. Pada $\mathrm{Zr}-2,5 \% \mathrm{Nb}$ Alloy, zirkonium masih mendominasi susunan materialnya. Namun, penambahan Niobium sebesar $2,5 \%$ di dalam paduan logam tersebut memberikan kemampuan termal yang makin baik. Hal ini terlihat dari nilai kapasitas panas dan konduktivitas panas dari $\mathrm{Zr}-2,5 \% \mathrm{Nb}$ alloy yang lebih besar daripada zircalloy-4. Selain itu, nilai ekspansi termal linier dari $\mathrm{Zr}-2,5 \% \mathrm{Nb}$ alloy juga lebih kecil dibandingkan dengan zircalloy-4.

D9 merupakan material yang bertipe austenitic. Material ini memiliki perilaku ekspansi termal dan konduktivitas termal yang serupa dengan stainless steel tipe 316. Material ini memiliki kandungan Nikel yang cukup banyak dan dapat menambahkan kemampuan dari sisi ketahanan terhadap karat dan stress corrosion. Selain itu, terdapat penambahan unsur karbon di dalam D9 yang digunakan untuk menstabilkan struktur besi yang austenitic. Paduan logam lain yang digunakan adalah HT9. Material ini memiliki sifat yang cukup mirip dengan stainless steel tipe 410 . Material ini bertipe martensitic. Material ini memiliki ketahanan terhadap korosi yang rendah karena kandungan nikelnya yang sedikit, namun material ini lebih kuat dan lebih tangguh. Nilai $k_{\text {eff }}$ selama proses operasi teras reaktor digambarkan melalui grafik sebagai berikut,
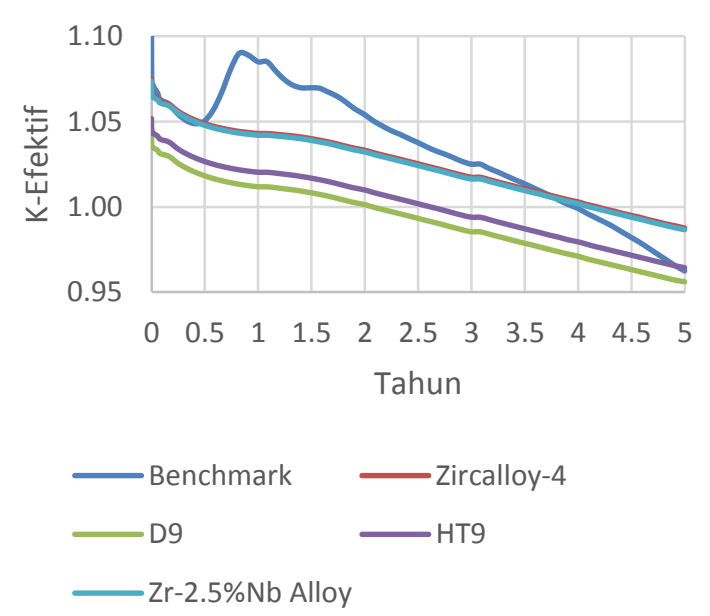

Gambar. 10. Nilai keff selama operasi teras reaktor pada variasi jenis kelongsong

Berdasarkan hasil simulasi yang telah dilakukan, didapatkan informasi bahwa teras reaktor yang menggunakan material kelongsong berupa baja tahan karat (stainless steel) secara neutronik memiliki kemampuan yang tidak cukup baik. Secara visual dapat dilihat bahwa variasi D9 dan HT9 memiliki nilai $k_{\text {eff }}$ yang lebih kecil sepanjang periode operasi teras reaktor dibandingkan dengan teras yang menggunakan kelongsong berbasis zirkonium. Teras reaktor dengan kelongsong D9 dan HT9 secara berurutan memiliki periode operasi reaktor sebesar 730,5 hari dan 940,5 hari. Hal ini cukup jauh bila dibanding dengan teras benchmark yang mampu beroperasi selama 1425,75 hari. Hal ini dapat disebabkan oleh adanya material yang memiliki tampang lintang serapan yang tinggi untuk neutron termal di dalam jenis kelongsong. Kandungan krom, vanadium, dan titanium dapat berkontribusi terhadap berkurangnya periode operasi reaktor karena ketiga unsur ini memiliki nilai tampang lintang serapan pada energi termal yang relatif besar dibandingkan dengan jenis logam yang lain.

Sementara itu, teras reaktor dengan kelongsong berbasis zirkonium memiliki kemampuan yang mirip dengan teras benchmark. Secara visual, perbedaan antara kelongsong zircalloy-4 dan $\mathrm{Zr}-2,5 \% \mathrm{Nb}$ alloy memberikan pengaruh yang tidak signifikan. Namun, bila ditelaah lebih dalam, teras dengan kelongsong $\mathrm{Zr}-2,5 \% \mathrm{Nb}$ alloy memiliki kemampuan neutronik yang lebih rendah dibandingkan teras dengan kelongsong zircalloy-4. Periode operasi teras reaktor dari teras dengan kelongsong zircalloy-4 dan $\mathrm{Zr}$ - 
$2,5 \% \mathrm{Nb}$ alloy secara berturut-turut adalah 1521 hari dan 1491. Perbedaan dari keduanya hanya terlampau 30 hari. Hal ini dapat disebabkan oleh perbedaan kandungan niobium yang ada di dalam kelongsong. Kandungan niobium ini cukup berarti dari sisi neutronik karena niobium memiliki tampang lintang serapan neutron yang cukup besar pada energi termal, yaitu 1,15 barn. Nilai ini memiliki pengaruh yang signifikan bila ditelaah kembali karena terkandung dalam bungkus pin bahan bakar yang digunakan di dalam teras reaktor.

Selain nilai $\mathrm{k}_{\text {eff }}$ selama periode operasi reaktor, nilai rasio konversi dari variasi ini juga dapat diketahui melalui grafik sebagai berikut,
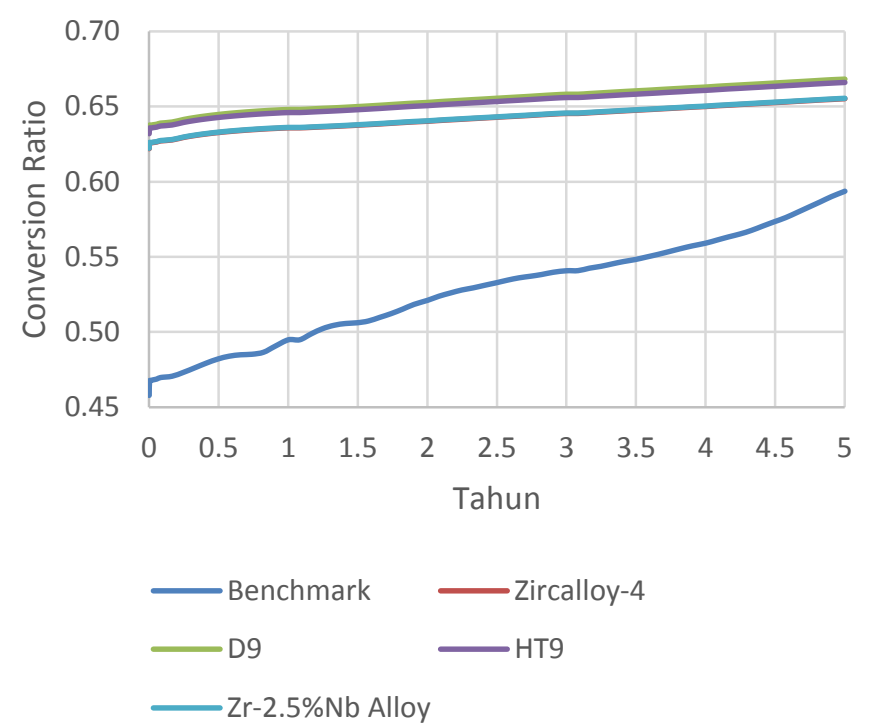

Gambar. 11. Hubungan rasio konversi selama operasi teras reaktor dalam variasi jenis kelongsong

Bila dibandingkan menggunakan parameter rasio konversi. Fenomena yang berkebalikan dengan nilai $\mathrm{k}_{\text {eff }}$ terjadi. Pada variasi ini, secara umum nilai rasio konversi dari teras reaktor dengan kelongsong berbasis baja tahan karat memiliki kemampuan yang lebih baik dibandingkan dengan teras reaktor yang menggunakan kelongsong berbasis zirkonium. Secara visual, dapat dilihat bahwa perbedaan antara kelongsong berbasis baja tahan karat dengan zirkonium tidak terlalu jauh, hal ini menunjukkan kemampuan konversi dari keempat variasi yang dapat dikatakan serupa. Namun, pada teras reaktor dengan kelongsong zirkonium, nilainya rendah karena proses transmutasi yang terjadi juga lebih sedikit dan juga proses konversi yang menjadi kelanjutannya menjadi lebih sedikit. Adanya niobium dalam $\mathrm{Zr}-2,5 \% \mathrm{Nb}$ alloy memengaruhi bagaimana perilaku teras reaktor dalam mengonversi material fertil menjadi material fisil. Dengan nilai serapan yang bertambah, kemungkinan hasil serapan tersebut menjadi aktinida yang kemudian terinduksi oleh neutron sehingga dikonversi menjadi material fisil juga semakin besar.

Fenomena yang serupa juga terjadi pada kelongsong berbasis baja tahan karat. Dengan kemampuan serapan yang tinggi dari material penyusunnya, D9 dan HT9 memiliki kemungkinan penyerapan material yang kemudian menghasilkan nuklida fertil lalu kemudian diinduksi neutron menjadi nuklida fisil yang lebih besar dibandingkan kelongsong berbasis zirkonium. Bila dilihat lebih jauh, D9 memiliki rasio konversi yang lebih baik dibandingkan dengan HT9, hal ini dikarenakan kandungan Nikel dan titanium di dalam baja D9 memberikan efek serapan yang lebih tinggi dibandingkan tungsten dan vanadium yang terkandung di dalam HT9. Meskipun perbedaan yang dimilikinya tidak signifikan, tapi sangat penting untuk mengetahui mengapa perbedaan tersebut terjadi.

Aktinida yang dihasilkan untuk variasi kelongsong zircalloy-4 adalah sebagai berikut.

Tabel. 9. Jumlah aktinida variasi kelongsong Zircalloy-4

\begin{tabular}{ccccc} 
Tahun & \multicolumn{4}{c}{ Aktinida (gram) } \\
\cline { 2 - 5 } & $U-235$ & $U-238$ & $P u-239$ & $P u-240$ \\
\hline 0 & 58.577 & 8.180 .400 & 569.810 & 271.930 \\
\hline 1 & 55.569 & 8.150 .700 & 542.470 & 269.920 \\
\hline 3 & 49.639 & 8.086 .700 & 490.500 & 264.380 \\
\hline 5 & 44.144 & 8.021 .000 & 443.360 & 257.360
\end{tabular}

Berdasarkan nilai $k_{\text {eff }}$ dan rasio konversi, dan jumlah aktinida, dipilihkan teras reaktor dengan kelongsong zircalloy-4 untuk menjadi acuan pada variasi berikutnya. Hal ini karena meskipun memiliki rasio konversi yang lebih kecil dibandingkan variasi yang lain, kemampuan neutroniknya cukup baik dan memiliki selisih yang cukup besar dibandingkan yang lain. Di sisi lain, nilai rasio konversi dari seluruh variasi ini masih lebih tinggi dibandingkan dengan teras benchmark, sehingga tidak masalah bila menggunakan teras yang memiliki rasio konversi yang paling kecil dibandingkan dengan yang lain. 


\section{KESIMPULAN}

Performa teras PWR integral memiliki perubahan yang signifikan pada saat bahan bakar diubah dari awalnya menggunakan $\mathrm{UO}_{2}$ menjadi MOX. Perubahan jumlah bahan bakar dan jenis kelongsong memberikan pengaruh yang signifikan pula. Secara umum, teras reaktor dengan menggunakan bahan bakar MOX memiliki performa yang lebih baik daripada teras berbahan bakar $\mathrm{UO}_{2}$. Teras PWR Integral yang memiliki performa terbaik adalah teras dengan $12 \% \mathrm{PuO}_{2}$, diameter teras $165 \mathrm{~cm}$, dan kelongsong zircalloy-4. Bila dilihat dari faktor-faktor yang memengaruhi, maka kesimpulan yang didapatkan adalah sebagai berikut,

1. Nilai Kekritisan $\left(\mathrm{k}_{\text {eff }}\right)$ pada periode operasi teras reaktor bertambah secara signifikan dari yang awalnya bernilai teras reaktor dapat beroperasi selama 1425,75 hari bisa bertambah menjadi 1521 hari. Pada parameter ini, variasi yang paling berpengaruh adalah variasi rasio $\mathrm{PuO}_{2}$ di dalam MOX,

2. Nilai rasio konversi yang dihasilkan oleh teras reaktor dengan bahan bakar MOX memiliki kecenderungan untuk tetap stabil dalam periode waktu tertentu. Perubahan nilai rasio konversi yang terjadi tidak sesignifikan apabila digunakan bahan bakar $\mathrm{UO}_{2}$,

3. Inventori aktinida dari teras reaktor yang menggunakan MOX memiliki tren penurunan yang stabil. Hal ini terjadi selama seluruh variasi sudah dilakukan. Hal ini menunjukkan bahwa tren penurunan tersebut adalah sifat yang melekat di dalam bahan bakar MOX,

\section{UCAPAN TERIMA KASIH}

Penulis mengucapkan Departemen Teknik Nuklir dan Teknik Fisika FT UGM yang telah menyediakan fasilitas bagi penulis untuk melakukan penelitian.

\section{DAFTAR PUSTAKA}

1. Direktorat Jenderal Energi Baru, Terbarukan, dan Konservasi Energi, Buku Statistik EBTKE 2016, Jakarta: Direktorat Jenderal EBTKE Kementerian Energi dan Sumber Daya Mineral, 2016.
2. Nuclear Energy Agency, Organisation for Economic Co-operation and Development, "Plutonium Management in the Medium Term," OECD/NEA, Paris, 2003.

3. NuScale Power, LLC, "NuScale Standard Plant, Design Certification Application, Reactor," NuScale Power, LLC, Oregon, 2016.

4. International Atomic Energy Agency, "Spent Fuel Reprocessing Options," IAEA, Vienna, 2008.

5. P. H. M. S. K. Koroush Shirvan, "The Design of a Compact Integral Medium Size PWR," Nuclear Engineering and Design, vol. I, no. 243, pp. 393-403, 2012.

7. World Nuclear Association, "Mixed Oxide (MOX) Fuel," 2017. [Online]. Available: http://www.world-nuclear.org/informationlibrary/nuclear-fuel-cycle/fuelrecycling/mixed-oxide-fuel-mox.aspx. [Accessed 8 April 2018].

7. K. Okumura, T. Kugo and K. Tsuchisashi, SRAC2006: A Comprehensive Neutronic Calculation Code System, Ibaraki-Ken: JAEA, 2007.

8. K. Okumura, COREBN: A Core Burn-up Calculation Module for SRAC2006, Ibaraki-ken: JAEA, 2007. 